\title{
The Evaluation of Influence of Different Types of Innovations on Financial Performance of Enlisted Companies of Tehran Stock Exchange, Case Study: Pharmaceutical Industry
}

\author{
Mansour Isvand Soltanabadi \\ Department of accountancy, college of accountancy,Islamic Azad University \\ International aducation cente of Persian gulf, Ahvaz, Iran; Email: isvand446@gmail.com
}

\author{
Doi:10.5901/ajis.2016.v5n2p69
}

\section{Abstract}

The objective of present study is to evaluate the effect of different types of innovation on financial performance of enlisted companies of Tehran Stock Exchange. The statistical population of present study covers enlisted companies of Tehran Stock Exchange (i.e. pharmaceutical industry) and the statistical sample includes 139 experts, managers and top managers. In this study, correlative-descriptive methodology is applied and questionnaire distribution is used to collect data. For data analysis, SPSS Software is employed. In the present study, the financial performance is defined as dependent variable. Innovation is the independent variable which is identified through the following 4 items: Organizational Innovation, Innovation in Product, Innovation in Process, and Innovation in Marketing. The findings of present study suggest that there is a significant association between types of innovation and financial performance of enlisted pharmaceutical companies of Tehran Stock Exchange. Among the underlying items of innovation, only innovation in marketing lacks significant association with financial performance but the significant associations of other items with financial performance is confirmed.

Keywords: Financial Performance, Organizational Innovation, Marketing Innovation, Innovation in Process, Innovation in Product, Enlisted Pharmaceutical Companies.

\section{Introduction}

Today, the progress of IT and increasing knowledge orientation of global economy have put organizations in a setting in which they have no choice but to draw upon their intangible assets to survive and to be the winner of the current global knowledge-oriented competition (Beik-Zade and Pour-Mohammadi, 2011). In fact, the organizations are currently facing a setting the dominant characteristic of which is increasing complexity, globalization and dynamicity. Therefore, the organizations are facing new challenges against their establishment and survival. Dealing with these challenges demands higher attention to development and reinforcement of skills and capabilities in realizing different types of innovations; organizations require these innovations to attain better performance in business world (Esmaili, 2011). In addition, the organizations should approach innovation as an essential strategy in the current era so as to survive in the new paradigm of competition among organizations which is completely competitive and knowledge-oriented. Along with identification of environmental changes so as to cope with them effectively, the organizations should identify the organization indicators affecting organizational innovation. In this manner, they can offer the most suitable responses. In the current knowledgeoriented and evolving setting, innovation has unprecedentedly drawn attentions to itself due to changed patterns of organizational competition and necessity of adaption with quick changes. That is why, one of the problems that organizational managers always face is the type of measures required for development and improvement of innovation in their organization (Zarin-Sabab, 2011).

On the other hand, among different methods of evaluating the performance of companies financial performance plays a significant role in literature of organization and management. Organizational management not only improves the market share of an organization through development of products and processes but also creates new markets and shapes the setting accordingly. These factors influence the determining factors of financial performance of companies such as increase of income, increase of operational profit, increased net profit, return on asset (ROA) and return on equity (ROE).

Although numerous writers and researchers emphasize the key role of organizational innovation in enhancing the financial performance but insufficiency of scientific studies on the association between these two factors is observed. This issue is doubly significant in enlisted companies of Tehran Stock Exchange which is one of the primary elements of national economy. 
Therefore, the researcher in the present study faces the question whether organizational innovation affects the financial performance of enlisted companies of Tehran Stock Exchange that are involved in pharmaceutical industry. In other words, could one attribute the financial performance of the companies enlisted in Tehran Stock Exchange to different types of innovation? In the end, it is hoped that the results of present study provide the managers and experts with essential information on improvement and development of different types of innovation as an important factor in development and improvement of financial performance,

\section{Literature Review}

Rahim-Nia et al (2008) in did a study called "The influence of emotional intelligence of managers on financial performance" on 320 employees of different branches of Eghtesad Novin Bank located in Tehran Province. Their findings suggested that emotional intelligence and its aspects (i.e. emotional self-evaluation, emotional evaluation of others, use of emotion and setting up emotion) have significant and positive association with financial performance of different branches of Eghtesad Novin Bank located in Tehran Province.

Zare' (2010) did a study titled "The investigation of factors affecting organizational innovation in Power Plant Projects Management Company (MAPNA)" based on confirmatory factor analysis. The results suggest that certain factors such as organizational structure, management style, job satisfaction, job involvement, organizational citizenship behavior and communication skills of managers are influential upon organizational innovation in MAPNA Company. These factors were identified through Delphi Technique. Among these factors, management style, job satisfaction, job involvement, and communication skills of managers were identified as significant factors affecting organizational innovation.

Rahman Seresht and Mazloomi (2004) did a survey called "The association of managerial performance of corporate investors with their financial performance". The focused on the enlisted companies of Tehran Stock Exchange and found out that different groups of owners do not equally benefit from power and alignment as influential upon financial performance of the company. In the end, the difference in ownership structures was able to explain certain variation in financial performance of the companies.

Hassani (2009) did a study titled "The investigation of the association between job characteristics and financial performance" on 168 employees of Governorship located in Bushehr Province through the methodology of correlation and attained the following finding: There is a significant association between job characteristics and financial performance. In addition, significant associations were found between diversity of skills and financial performance, between significance of task and financial performance, between meaningfulness of task and financial performance, and between feedback and financial performance.

Jane et al (2004) did a survey on the effects of innovation on performance. The statistical population and sample of present study included the companies of manufacturing industry. Following regression analysis, the findings suggested that organizational innovation, innovation in process and innovation in product affect the performance.

Subramanian and Nilakania (1996) did a survey called "Innovation: Investigation of the association among organizational innovation determiners, types of innovation and organizational performance". The statistical population and sample of present study included the companies of aviation industry. Based on regression analysis and exploratory analysis, the findings suggested that the support of top managers and financial supports for accepting innovation, integration of knowledge management and job processes and public consensus on accepting innovation are among the most significant determiners. In addition, the findings suggested that there is an association between types of innovation and organizational performance.

Hughman et al (2010) conducted a survey on the positive effects of organizational creativity on organizational performance. The statistical population and sample of the study included 160 official stuff of Midwestern (United States) based on regression analysis. The findings suggested that organizational creativity is influential upon organizational performance. The structural aspects, organizational setting, human resources competencies and creativity strategy have significant influence upon organizational performance. No evidence was found regarding a significant influence of aspects of collection and distribution on organizational performance.

Peter (2008) conducted a survey called "Technological innovation and organizational performance with modifying role of organizational culture in German companies". His findings suggest a significant association between technological innovation and organizational performance. In addition, the organizational culture was able to reinforce the intensity of association between technological innovation and organizational performance.

Stoart (2012) studied the association between organizational innovation and job redesign in a sample consisting of 35 companies active in construction industry. His methodology in this study was structural equation modelling (SEM). The 
findings suggested that job redesign is positively associated with organizational innovation. In addition, there is a significant association between job independence and meaningfulness of task as well as between diversity of skills and organizational innovation. The job independence is not significantly associated with organizational innovation. In addition, the findings suggest that among the aspects of job redesign, diversity of skill and job feedback have the highest and the least influence on organizational innovation respectively.

Ten Brummelhuis et al (2008) studied the association between job participation and financial performance in 17 samples of restaurants and coffee shops of Manchester (England) based on regression analysis based on structural equation modelling. The findings suggest that preoccupation with work and inclination toward it, as the top two aspects of job participation, have positive association with financial performance. While ability does not have a significant and positive association with financial performance, the number of children is negatively associated emotional burnout.

\section{Research Hypotheses}

\subsection{Main Hypothesis}

1- There is a significant association between innovation and financial performance of pharmaceutical companies enlisted in Tehran Stock Exchange.

\subsection{Secondary Hypotheses}

1- There is a significant association between organizational innovation and financial performance of pharmaceutical companies enlisted in Tehran Stock Exchange.

2- There is a significant association between innovation in product and financial performance of pharmaceutical companies enlisted in Tehran Stock Exchange.

3- There is a significant association between innovation in process and financial performance of pharmaceutical companies enlisted in Tehran Stock Exchange.

4- There is a significant association between innovation in marketing and financial performance of pharmaceutical companies enlisted in Tehran Stock Exchange.

\section{Conceptual Model}

In the present study, we intend to discuss the influence of different types of organizational innovation on financial performance of companies enlisted in Tehran Stock Exchange (i.e. pharmaceutical industry).

As an independent variable, organizational innovation (as a predictor) includes the three aspects of manufacturing innovation, innovation in process and administrative innovation. Financial performance acts as a dependent variable (criterion variable).

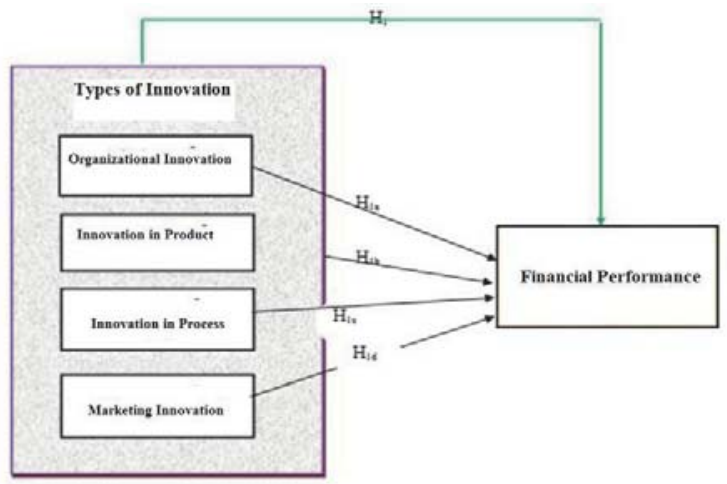

Figure 1. Theoretical Framework of Present Study (Source: Gunday et al, 2014) 


\section{Data Collection and Analysis}

In the present study, SPSS Software and different methods of descriptive and inferential statistics for data analysis and testing of hypotheses. In descriptive statistics, the researcher collects and summarizes the quantitative information of the samples so as to describe the characteristics of the studied sample. In inferential statistics, the researcher investigates one or multiple samples and uses statistical methods and models so as to infer the parameters and characteristics of the whole statistical population from the typical indicators and characteristics of the sample. In other words, the results of the sample are extended to the whole statistical population through inferential statistics. Without it, a study will lack scientific validity. The tests conducted in the present study include:

- Descriptive statistics so as to examine the characteristics of respondents and statistical population.

- Cronbach's alpha test to determine the reliability of the questionnaire

- Application of correlation analysis

\subsection{Data Analysis}

\subsubsection{Main Hypothesis:}

There is a significant association between types of innovation and financial performance of pharmaceutical companies enlisted in Tehran Stock Exchange.

HO: There is no significant association between types of innovation and financial performance of pharmaceutical companies enlisted in Tehran Stock Exchange $(\mathrm{p}=0)$.

H1: There is a significant association between types of innovation and financial performance of pharmaceutical companies enlisted in Tehran Stock Exchange $(\rho \neq 0)$

Table 1. Results of Correlation Coefficient for Main Hypothesis

\begin{tabular}{|c|c|c|c|c|}
\hline & & & Types of Innovation & Financial Performance \\
\hline \multirow{6}{*}{ Pearson Correlation Coefficient } & \multirow[t]{3}{*}{ Types of Innovation } & Correlation Coefficient & 1 & $0.272^{*}$ \\
\hline & & \begin{tabular}{|l|l} 
Level of Significance (Two Ranges) \\
\end{tabular} & & 0.001 \\
\hline & & Number & 139 & 139 \\
\hline & \multirow[t]{3}{*}{ Financial Performance } & Correlation Coefficient & $0.272^{*}$ & 1 \\
\hline & & \begin{tabular}{|l|} 
Level of Significance (Two Ranges) \\
\end{tabular} & 0.001 & \\
\hline & & Number & 139 & 139 \\
\hline
\end{tabular}

The results of the above table suggest that the significance level associated with Pearson correlation coefficient and used for testing $\mathrm{HO}$ of the main hypotheses is equal with 0.001 which is less than 0.05 (sig<0.05). Therefore, at 95 percent confidence level one could deny the zero hypothesis and its opposing hypothesis $(\rho \neq 0)$ is confirmed. As a result, one could state that there is a significant association between types of innovation and financial performance of pharmaceutical companies enlisted in Tehran Stock Exchange.

\subsubsection{Secondary Hypothesis 1}

There is a significant association between organizational innovation and financial performance of pharmaceutical companies enlisted in Tehran Stock Exchange.

$\mathrm{HO}$ : There is no significant association between organizational innovation and financial performance of pharmaceutical companies enlisted in Tehran Stock Exchange. $(p=0)$.

H1: There is a significant association between organizational innovation and financial performance of pharmaceutical companies enlisted in Tehran Stock Exchange $(\rho \neq 0)$ 
Table 2. Results of Correlation Coefficient for Secondary Hypothesis 1

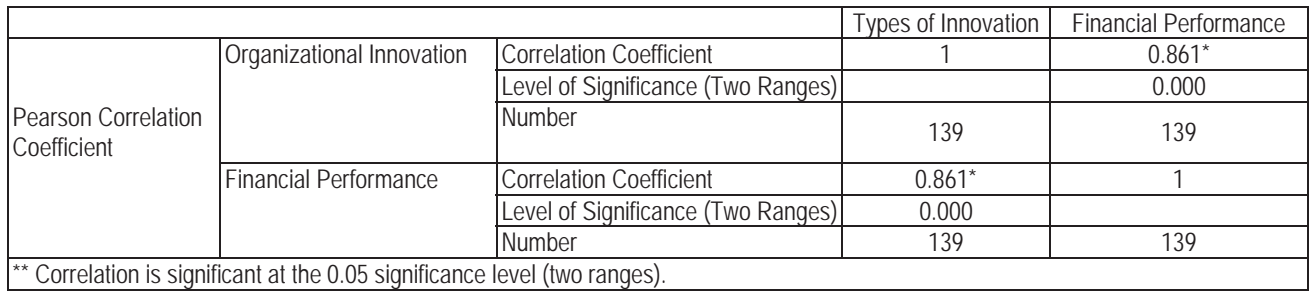

The results of the above table suggest that the significance level associated with Pearson correlation coefficient and used for testing $\mathrm{HO}$ of the main hypotheses is equal with 0.000 which is less than $0.05($ sig<0.05). Therefore, at 95 percent confidence level one could deny the zero hypothesis and its opposing hypothesis $(\rho \neq 0)$ is supported. As a result, one could state that there is a significant association between organizational innovation and financial performance of pharmaceutical companies enlisted in Tehran Stock Exchange.

\subsubsection{Secondary Hypothesis 2}

There is a significant association between innovation in product and financial performance of pharmaceutical companies enlisted in Tehran Stock Exchange.

HO: There is no significant association between innovation in product and financial performance of pharmaceutical companies enlisted in Tehran Stock Exchange. $(p=0)$.

H1: There is a significant association between innovation in product and financial performance of pharmaceutical companies enlisted in Tehran Stock Exchange $(\rho \neq 0)$.

Table 3. Results of Correlation Coefficient for Secondary Hypothesis 2

\begin{tabular}{|c|c|c|c|c|}
\hline & & & Types of Innovation & Financial Performance \\
\hline & Innovation in Product & Correlation Coefficient & 1 & $0.208^{*}$ \\
\hline & & Level of Significance (Two Ranges) & & 0.014 \\
\hline Pearson Correlation Coefficient & & Number & 139 & 139 \\
\hline & Financial Performance & Correlation Coefficient & $0.208^{*}$ & 1 \\
\hline & & Level of Significance (Two Ranges) & 0.014 & \\
\hline & & Number & 139 & 139 \\
\hline
\end{tabular}

The results of the above table suggest that the significance level associated with Pearson correlation coefficient and used for testing $\mathrm{HO}$ of the main hypotheses is equal with 0.014 which is less than $0.05(\mathrm{sig}<0.05)$. Therefore, at 95 percent confidence level one could deny the zero hypothesis and its opposing hypothesis $(\rho \neq 0)$ is supported. As a result, one could state that there is a significant association between innovation in product and financial performance of pharmaceutical companies enlisted in Tehran Stock Exchange.

\subsubsection{Secondary Hypothesis 3:}

There is a significant association between innovation in process and financial performance of pharmaceutical companies enlisted in Tehran Stock Exchange.

HO: There is no significant association between innovation in process and financial performance of pharmaceutical companies enlisted in Tehran Stock Exchange $(p=0)$.

H1: There is a significant association between innovation in process and financial performance of pharmaceutical companies enlisted in Tehran Stock Exchange $(\rho \neq 0)$. 
Table 4. Results of Correlation Coefficient for Secondary Hypothesis 3

\begin{tabular}{|c|c|c|c|c|}
\hline & & & Types of Innovation & Financial Performance \\
\hline & Innovation in Process & Correlation Coefficient & 1 & $0.836^{*}$ \\
\hline & & Level of Significance (Two Ranges) & & 0.000 \\
\hline Pearson Correlation Coefficient & & Number & 139 & 139 \\
\hline & Financial Performance & Correlation Coefficient & $0.836^{*}$ & 1 \\
\hline & & Level of Significance (Two Ranges) & 0.000 & \\
\hline & & Number & 139 & 139 \\
\hline
\end{tabular}

The results of the above table suggest that the significance level associated with Pearson correlation coefficient and used for testing $\mathrm{HO}$ of the main hypotheses is equal with 0.000 which is less than $0.05(\mathrm{sig}<0.05)$. Therefore, at 95 percent confidence level one could deny the zero hypothesis and its opposing hypothesis $(\rho \neq 0)$ is supported. As a result, one could state that there is a significant association between innovation in process and financial performance of pharmaceutical companies enlisted in Tehran Stock Exchange.

\subsubsection{Secondary Hypothesis 4:}

There is a significant association between marketing innovation and financial performance of pharmaceutical companies enlisted in Tehran Stock Exchange.

HO: There is no significant association between marketing innovation and financial performance of pharmaceutical companies enlisted in Tehran Stock Exchange $(\mathrm{p}=0)$.

$\mathrm{H} 1$ : There is a significant association between marketing innovation and financial performance of pharmaceutical companies enlisted in Tehran Stock Exchange $(\rho \neq 0)$.

Table 5. Results of Correlation Coefficient for Secondary Hypothesis 4

\begin{tabular}{|c|c|c|c|c|}
\hline & & & Types of Innovation & Financial Performance \\
\hline \multirow{6}{*}{ Pearson Correlation Coefficient } & \multirow[t]{3}{*}{ Marketing Innovation } & Correlation Coefficient & 1 & $0.105^{*}$ \\
\hline & & \begin{tabular}{|l|} 
Level of Significance (Two Ranges) \\
\end{tabular} & & 0.065 \\
\hline & & Number & 139 & 139 \\
\hline & \multirow[t]{3}{*}{ Financial Performance } & Correlation Coefficient & $0.105^{*}$ & 1 \\
\hline & & \begin{tabular}{|l|} 
Level of Significance (Two Ranges) \\
\end{tabular} & 0.065 & \\
\hline & & Number & 139 & 139 \\
\hline
\end{tabular}

The results of the above table suggest that the significance level associated with Pearson correlation coefficient and used for testing $\mathrm{HO}$ of the main hypotheses is equal with 0.065 which is more than 0.05 (sig>0.05). Therefore, at 95 percent confidence level one could support the zero hypothesis and its opposing hypothesis $(\rho \neq 0)$ is denied. As a result, one could state that there is no significant association between marketing innovation and financial performance of pharmaceutical companies enlisted in Tehran Stock Exchange.

\subsection{Regression Analysis}

Table 6. ANOVA Analysis

\begin{tabular}{|l|c|c|c|c|c|}
\hline Aspect & Sum of Squares & Degree of Freedom & Mean Square & F-statistic & Level of Significance \\
\hline Regression & 332.077 & 5 & 66.415 & & \\
\hline Remaining & 85.347 & 133 & 0.642 & 103.498 & 0.000 \\
\hline Sum & 417.424 & 138 & & & \\
\hline
\end{tabular}

Based on the result of ANOVA, it is clear that types of innovation is influential upon financial performance.

HO: Types of organizational innovation are not predictors of financial performance.

$\mathrm{H1}$ : Types of organizational innovation are predictors of financial performance. 
Table 7. Results of Regression Test

\begin{tabular}{|l|l|c|c|c|c|l|}
\hline Independent Variable & Dependent Variable & Standard Error & Beta & t-statistic & Level of Significance & Meaning of Test Result \\
\hline Types of Innovation & Financial Performance & 0.066 & 0.015 & 0.206 & 0.837 & H0 Supported \\
\hline Innovation in Product & Financial Performance & 0.075 & 0.055 & 7.53 & 0.000 & H0 Denied \\
\hline Innovation in Process & Financial Performance & 0.074 & 0.448 & 5.96 & 0.000 & H0 Denied \\
\hline Marketing Innovation & Financial Performance & 0.054 & 0.021 & 0.182 & 0.615 & H0 Supported \\
\hline Organizational Innovation & Financial Performance & 0.075 & 0.055 & 7.53 & 0.000 & H0 Denied \\
\hline
\end{tabular}

As observed in the above table, the significance levels for types of innovation and marketing innovation are higher than 0.05 and as a result they are insignificant. In other word, HO hypothesis is supported. On the other hand, the levels of significance for innovation in process, innovation in product and organizational innovation are less than 0.05 . As a result, they are significant and $\mathrm{HO}$ hypothesis is denied.

\section{Discussion and Conclusion}

The present study was done based on the objective of examining the influence of different types of organizational innovation on financial performance of the companies. The statistical population in the present study included the enlisted companies of Tehran Stock Exchange (i.e. pharmaceutical industry) and 139 experts, managers and top managers were included in the sample.

The present study is applied in objective and exploratory in its description method. In the present study, the reliability coefficient of the questionnaire was 0.737 . In addition, the face validity was confirmed via experts' comments. For data analysis and testing hypotheses, K-S test, correlation test and regression analysis were used.

In regard to types of organizational innovation and financial performance within and without the country, numerous studies could be found. However, there is no study on determining the association between the two variables in Iran.

The results of present study suggest:

- There is a significant association between organizational innovation and financial performance of pharmaceutical companies enlisted in Tehran Stock Exchange.

- There is a significant association between innovation in product and financial performance of pharmaceutical companies enlisted in Tehran Stock Exchange.

- There is a significant association between innovation in process and financial performance of pharmaceutical companies enlisted in Tehran Stock Exchange.

- There is no significant association between marketing innovation and financial performance of pharmaceutical companies enlisted in Tehran Stock Exchange.

During the review of the results of studies conducted abroad, it was observed that in most of the cases there was a significant and positive association of organizational aspect, product, technology and marketing with financial performance. From this perspective, the results of present study confirms the results of other foreign studies conducted in the past about the association between innovation and financial performance.

A study called "The investigation of the positive effects of organizational performance on organizational performance" was done by Subramanian and Nilakanta (1996) among employees of aviation industry. They found out that the support of top managers and financial support for accepting innovation, integration between knowledge management and job processes and public consensus on accepting innovation were among the most significant determiners. In addition, the findings suggested that there is a significant association between types of innovation and organizational performance.

The results of present study matches two of Subramanian and Nilakanta (1996). Our findings suggest that innovation and most of its aspects (i.e. organizational, product, technological and marketing) have significant association with financial performance. Some of the associations were strong and some were weak,

In another study, Jane et al (2004) examined the effects of innovation on performance. The statistical population and sample of this study were the companies belonging to manufacturing industry. Following regression analysis, the findings suggested that organizational innovation, innovation in product and innovation in process influences the performance of a company. These results matches ours. 


\subsection{Suggestions for Future Studies}

\subsubsection{Suggestions based on Hypothesis 1}

The first hypothesis assumed that there is a significant association between organizational innovation and financial performance of enlisted pharmaceutical companies of Tehran Stock Exchange.

For response to and dealing with demands, the managers should use flexible and organic structures. They should generate higher flexibility in executing the organizational laws, regulations and guidelines.

Exclusion of hierarchy: The modern organizations should empower the frontline managers directly involved in doing the affairs through non-concentrated decisions and reduced hierarchies. In this manner, they may be able to increase creativity. The frontline managers should be able to determine their strategies and correct them if needed. Ghoshal and Bartlett (2002) recommended that frontline managers should be encouraged to make decisions on organizational activities themselves; the top managers should only attempted to create a setting for supporting and satisfaction of the needs of frontline managers.

\subsubsection{Suggestions based on Hypothesis 2}

Innovation in product has significant influence on financial performance of enlisted pharmaceutical companies in Tehran Stock Exchange.

In this regard, the following suggestions are made for enhancing organizational innovation and improved financial performance of enlisted pharmaceutical companies in Tehran Stock Exchange.

it seems that that by small improvement of organizational setting, the managers may be able to generate the required conditions for application of employees' new ideas and encouraging them to freely offer and test their innovative ideas so that the company turns into a completely innovative one. Along with the execution of new ideas offered by employees and encouraging them to raise more similar suggestions, the organizations should set sufficient time for testing and operationalizing the ideas freely.

\subsubsection{Suggestions based on Hypothesis 3}

The innovation in process exerts significant effect on financial performance of pharmaceutical companies enlisted in Tehran Stock Exchange.

In regard to this hypothesis, the following suggestions are made to increase organizational innovation and to improve the financial performance of enlisted pharmaceutical companies in Tehran Stock Exchange.

The top organizational manager should show his/her inclination to take risks in finding new growth opportunities to the employees.

The executive managers should consistently search for new and unusual solutions for the problems. They should fulfil this through "ideation"-enhancing employees.

In the company, the new methods of fulfilling procedures and tasks should be sought and tested. In addition, those who do the jobs differently should be rewarded. The following items are further suggestions for future studies:

- Considering the obtained result, it is suggested to test the hypothesis in a more extensive range, namely a larger society or in national scale.

- Undoubtedly, conducting a similar study in different public and private companies along with comparison of results will contribute to further studies.

- The future researchers are advised to study the association between innovation and organizational performance as the main objective of the organizations.

- In addition, the future researchers are advised to examine the factors affecting improved creativity in organizations.

\section{References}

Ahmedian, A,. Aksar-Afsharo, M, A \& Shekari, H. (2011). The study of the association of knowledge recession with organizational learning and innovation in higher education centers of Yazd City, Quarterly of Organizational Culture Management, 9 (2),131154.

Arabi, M, R. (2014). The status of Iran in innovation and global competition, M. A. Dissertation, Business Management, Alame-Tabatabai 
University.

Azar, A \& Momeni, M. (2009). Statistics and its application in management, Tehran, Samt Press, 2.

Beik-Zade, Gh \& Pour-Mohammadi, A, R. (2010). The study and analysis of the association between innovation and position of human resources management based on the models of Nile, Snow and Shoulder-Jackson, First National Conference of Management, Innovation and Entrepreneurship in Shiraz.

Bordbar, M \& Konjkav, M. (2010). Strategic measures for human resources management and innovative performance with emphasis on the role of knowledge management, Two-monthly of Police Human Development, 6 (24).

Brummelhuis, T., Bakker, B \& Euwema, C. (2011).The relationship between organizational Innovation and Job redesign. Journal of Vocational Behavior, 76, 461-469.

Chopani, H. (2011). The study of association between transformational leadership and inclination toward organizational creativity in Alborz Insurance Company, M.A Dissertation of Business Management, Tehran University.

Fishani, T. (1999). Innovation and creativity in people and organizations, Termeh Press, Tehran.

Gholam-pur, A. (2000). Creativity and innovation in educational organizations, Quarterly of Management in Education Organization, 25.

Habib-Pour, K \& Safari, R. (2009). A comprehensive guide to application of SPSS in surveys (Quantitative data analysis), Tehran, Motafakeran Press.

Haffman, C.. Ulusoy, G,. Kilic, K \& Alpkan, L. (2010). Organizational creativity and organization performance, Administrative Science Quarterly, 29 (3), 392-409.

Jin, E, C \& Terblanche, F. (2004). The effect of organizational innovation on performance. European Journal of Innovation Management, $6(1), 64-74$

Khaki, Gh. (2008). Methodology of management, Publication Center of Islamic Azad University, Tehran.

Khodadad-Hosseini, H \& Azizi, Sh. (2006). Strategic management and planning: A comprehensive approach, Tehran, Safar Press, 1.

Rahim-Nia, N \& Armin, M. (2008). The study of the influence of managers' emotional intelligence on financial performance, Business Studies, 64.

Rahman-Seresht, H \& Mazloomi, N. (2005). The association of managerial performance of corporate investors with financial performance of these institutes for enlisted companies of Tehran Stock Exchange, Management Studies, Tehran, 37.

Rezvan, M \& Graili-Nejad, R. (2011). The measurement of innovation and factors affecting it among Iran-Khordro managers, M.A. Dissertation of Alama-Tabatabi University, Tehran.

Sadeghi Mal-Miri, M. (2007). Innovation (systemic approach, individual, group, organization), Imam Hossein University Press.

Salajeghe, M \& Nazeri, A. (2008). The association of emotional intelligence with extent of creativity and innovation among employees of Tavanir Organization, Masterly Dissertation, Islamic Azad University of Tehran.

Shariat-Panahi, N. (2014). A model for entrepreneurial innovation in manufacturing businesses of Iran, PhD Dissertation, AlamaTabatabai University.

Smith, P \& Tosey, P. (2009) Assessing the learning organization: part 1-theoretical foundations. The Learning Organization Journal, 6(2). $70-75$

Subramanian, H \& Nilakanta, D, G. (1996). Innovation: Survey of relationship between organization innovation, the type of innovation and organizational performance. Journal of World Business, 45 (2), 105-108.

Zare. (2010). The study of factors affecting organizational innovation in MAPNA Company, Masterly Dissertation, Alama-Tabatabai University of Tehran.

Zarin Sabab, M \& Salari, S. (2012). Intellectual capital management: A new approach to development and improved organizational improvement, Entrepreneurship Center of Sharif Industrial University.

Zarin Sabab, M. (2011). The study of association between intellectual capital and employees' inclination toward organizational creativity in Science and Technology Park of Tehran University, M.A Dissertation of Department of Psychology and Educational Sciences, Tehran University. 
